Studia Anglica Posnaniensia 47, 2-3, 2012

doi: 10.2478/v10121-012-0006-8

\title{
LITERATURE
}

\section{BETWEEN HABITS OF THE HEART AND COPULATION OF CLICHÉS: SOME POPULAR AMERICAN STORIES, MORES AND SHIBBOLETHS}

\author{
JANUSZ SEMRAU
}

Adam Mickiewicz University, Poznań

and

University of Humanities and Social Sciences, Warsaw

\begin{abstract}
From the very beginning, all manner of ideas, concepts and conceits have been advanced to explain America and Americans - as much to themselves as to others. The paper presents a historical-literary compilation of popular notions of 'Americanness' in the guise of random de Tocquevillian observations in general circulation. This is to provoke the question about the degree to which this kind of pervasive discourse may reflect the so-called habits of the heart, as against how at a certain point it may lapse into a Nabokovian copulation of clichés. ${ }^{1}$
\end{abstract}

\footnotetext{
I here mean ... not only moeurs in the strict sense, which might be called the habits of the heart, but also ... different notions possessed by men, the various opinions current among them.

(de Tocqueville [1835-1840] 1966: 264)

Thus action [becomes] ... limited to the copulation of clichés.

(Nabokov [1955] 1997: 313)
}

\footnotetext{
1 This paper is an extension of Semrau (2012b) and an illustration of the pivotal argument of Semrau (2012a). Cf. also Semrau (2011).
} 
Even though in more sense than one most of them were 'separatists' and 'independents', it was not exactly the 'self' that the first permanent Caucasian immigrants to the New World celebrated after their arduous, over two-month-long transatlantic voyage. Informed equally by high-flung idealism and sheer practical necessity, the future United States was originally envisaged as an exercise in exemplary social cohesion: as ethos, body politic and territory. The Mayflower passengers famously pledged all submission to the general good of the colony, reinforced soon after by the delivery aboard the Arbella of a communal model in which the care of the public was to over-sway all particular respects. A matter of both conviction and persuasion, a discourse as much sacred as secular, to assert oneself properly in terms of private and public identity was to embody the goals of nonseparating congregationalism. Circumscribed by simultaneous selfrighteousness and self-abasement, as well as supervised by communal vigilance, individual sense of freedom and of liberty as such was to be exercised in a way of voluntary obedience and general accountability. On some fundamental level, however, the compact and contract to forge a rigorously controlled commonwealth (gone so far as the taking away of personal property) was soon found to breed so much "confusion and discontent" that the settlers were at length allowed to keep the fruit of their labour "every man for his own particular" and at least in that regard "trust to themselves" (Bradford [1646] 1991: 72). ${ }^{2}$

With only a background impetus of history, essentially of their own evergrowing numbers, on the surging tide of diversity and pent-up energies, the colonists managed to surmount all kinds of prohibitive ideological proclamations, demarcations, cartographic lines, as well as natural boundaries. It is believed that only people who no longer saw themselves merely as immigrants but specifically as Americans could have so radically reinvented a sense of their spatial and existential orientation. All these processes, hardly a calculated grand strategic design, as is often claimed today, gained momentum at the beginning of the nineteenthcentury when "self-fueling" (Newfield 1996: 17) propelled individuals as fast and as far as their impulses would drive them, in what they pseudo-legitimately perceived as terra nullia, or vacant wilderness. Half-way through the nineteenth century, a commentator in The New Englander ([Review] 1850: 429) metaphorized this whole phenomenon as an unstoppable movement of an army of locusts - "the rear ones constantly flying over the front, to find themselves soon again in the rear and so urged to another flight". Just a couple of decades later, to Henry Adams (1918: 237) the American society profiled as a long, loose,

2 From the outset the American Canaan seems to have been a contradiction in terms: "On the one hand the people were being taught that their first duty no longer was to the absolutist power centered in faraway England. On the other hand their nascent liberties were being rightly restrained by ... their own communal church" (Oliver 1965: 8). 
stretched and straggling caravan - "trying, almost as blindly as an earthworm, to realize and understand itself; to catch up with its own head, and to twist about in search of its tail". ${ }^{3}$ As no nation of this size had ever expanded quite so rapidly in a space quite so large, it is small wonder that at the beginning of the twentieth century even Owen Wister, the author of the first full-fledged Western, should have been struck by insufficient social confluence and a lack of condensed common identity: "We're not nearly so closely knit together here" (Wister 1920: 215). ${ }^{4}$ Having relaxed or outright lost its sense of a shared covenant, continually converging and diverging, progressing and regressing, compacting and refracting, America seems to have in effect engendered a lasting "dissonance of parts and people" - as registered in nascent postmodern diction by William H. Gass (1968: 186) in In the heart of the heart of the country. Alexis de Tocqueville ([18351840] 1966: 25) argues sententiously that the circumstances accompanying the birth and contributing to the growth of a nation are likely to affect permanently the rest of its civilizational career.

It is accepted as a literal matter of course that the most distinctive protagonists of U.S. fiction tend to be "socially marginal" (Franzen 2003: 89). This general appreciation has been articulated probably most succinctly by Poirier (1966: 237; emphasis added): “To be 'outside American society' is of course to be in the great American literary tradition". It has been suggested that the paradigmatic American story dramatizes a confrontation of the individual with the promise that s/he will be able to achieve complete self-definition, informed by the assurance that individuals come before society, that they can exist in some profoundly meaningful sense prior to as well as apart from it. Ostensibly, to pastiche Nathaniel Hawthorne's and Henry David Thoreau's respective personal comments about Ralph Waldo Emerson (quoted in Julian Hawthorne [1884: 293]), the classic American protagonist appears to be a seeker for no one knows exactly what; it is somebody likely to assume opposition even where there seems to be no need for any difference of opinion. Emblematically, Ishmael's inexplicable periodic "hypoes" bring him for no obvious reason precari-

Cf. a more contemporary comment: "We are misled if we think of a westward moving line of settlement advancing like the front ranks of an army ... These were not men moving ever toward the west, but men ever moving in the west. The churning, casual, vagrant, circular motion around and around was as characteristic of the American experience as the movement in a single direction" (Boorstin 1965: 95).

4 Almost immediately, "the rapid settlement of the West during the first half of the nineteenth century weakened such earlier institutions of social control as the family, church, bench and bar, landholding and merchant elites, and the state" (Miller 1970: 54-55). 
ously close to "deliberately stepping into the street, and methodically knocking people's hats off" (Melville [1851] 1983a: 795). In the popular contemporary cultural rhetoric, there looms the figure of the nonchalant outsider: a cool-hand rebel without a (good) cause, with a trademark sneer as the all-purpose vindication of the defiantly self-assertive stance.

Being conspicuously at odds with the organized society, unwilling or unable to subscribe to its values and norms, practices and ways, is not simply borne out of the apprehension that society sits cold and statuesque, or out of the recognition that man might be physically as well as metaphysically unable to synchronize with the oppressive monotony of demand, out of the vague premonition that one's life is circumscribed, circumferential, and altogether too close to the centre. The whole issue appears to find a much larger rationale in Thoreau's ([1854] 1975a: 359) exasperated "wherever a man goes, men will pursue and paw him with their dirty institutions"; or in Emily Dickinson's ([c. 1865] 1960: 134) fundamentalist trepidation of "being theirs". Society is perceived thereby as the supreme custodian of the predictability of human behaviour, as the selfappointed curator of decorum, stability and permanence. It is recognized as shrewd, swift and ruthless in detecting those who do not subscribe to its ways. In "Much madness is divinest sense", Dickinson (1960: 8) reflects on how it is enough to demure, and "- -you're straightway dangerous"; and as such deserving to be "handled with a chain". Hawthorne projects it as a most disquieting realization that one's most vital interests fall under the control of ruthless officials: "Strange, too, ... to observe [how they] grow cruel, merely because they possess... the power of inflicting harm. If the guillotine, as applied to officeholders, were a literal fact, instead of one of the most apt of metaphors, it is my sincere belief, that [they would] chop... off all our heads" (Hawthorne [1850] 1983a: 153-154). The apprehension of society as the hostile Other equipped with the monopoly of perfidious and violent action is particularly emotively rendered in James Fenimore Cooper's The pioneers ([1823] 1964: 339), where local authorities driven by morbid curiosity and sheer greed organize in the name of the law a posse-invasion of an old hunter's retreat: "You will form yourselves in a complete circle round his hut, and at the words 'advance,' ... you will rush forward and, without giving [him] time for deliberation, enter his dwelling by force and make him your prisoner". Emerson's overall philosophical assessment ([1841] 1983a: 261) sounds unequivocal enough: "Society everywhere is in conspiracy against the manhood of every one of its members". Even entertaining standard codes of being simply embodied, emplaced and em-

Tom Wolfe (1968: 235) famously identifies a typical response generated by this kind of ambience in his The electric kool-aid acid test: "If society wants me to be an outlaw ... then I'll be an outlaw, and a damned good one". 
ployed, Americans have always been likely to find themselves "pent up in lath and plaster - tied to counters, nailed to benches, clinched to desks" (Melville [1851] 1983a: 796). ${ }^{6}$ Practically any formal group allegiance is likely to be associated sooner or later with excessive demands, shackling responsibilities and coercive laws. While the vehemence and radicalism of these enunciations do not exactly correspond to the benign image of the sages of American Romanticism, it is intriguing to discover the same stance in the early-twentieth century rhetoric: "Society, as we have seen, is one vast conspiracy for carving one into the kind of statue it likes, and then placing it in the most convenient niche it has" (Bourne [1913] 1992: 133), through the mid-century phraseology of the "vastness of America's machinery of depersonalization" (Viereck 1956: 21), to one of the most seminal modern literary studies built round the thesis of "an abiding American dread that someone else is patterning your life, that there are all sorts of invisible plots afoot to rob you of your autonomy of thought and action, that conditioning is ubiquitous" (Tanner 1971: 15). ${ }^{7}$ The ultimate presentiment is that to live in America is to be beset by "fear, anxiety and insecurity", to be besieged by potential "harm" and "evil intent" (Sardar and Davies 2004: 29). It is only natural that the shibboleths: "You got to be tough" (Hemingway [1923] 1993a: 125) and "Each must be armed" - all-too-often literally with "musket and pike" (Emerson [1860] 1983f: 1067) - should be (still) readily recognized, followed and well-respected. ${ }^{8}$

Symbolically, the troubled relationship between the individual and the commonwealth is particularly aptly projected by the following mid-nineteenth-

6 According to Anderson (1972: ix), what marks a superior - 'imperial' - American self (as projected supposedly classically by Ralph Emerson, Walt Whitman and Henry James) is the recognition that the worst thing a man could do is to accept the conditions of society/community and to "pin" oneself to a particular role. Cf. the following reading of canonical American fiction: "[T]he prospect of immersion in social experience, with its potential for moral confusion, self-exposure, and self-doubt, produces a response that often borders on terror, or periodically explodes in scorn and disgust. ... The barbarities of the social world thus serve as both motive and justification for the hero's withdrawal" (Rowe 1988: 134-135).

7 Some of Tanner's tenets draw on the countercultural recognitions of the late 1950's, such as that of the hipster, whose declared goal (courtesy of Norman Mailer) was to keep out of the society which was doing everything in its power to make everyone over in its own image. In The return of the vanishing American (1968), Leslie Fiedler suggests with a big sweep that the kin figures of the beatnik and the hippie descend from the frontiersman and the cowboy, as well as being heirs of the free-spirited Native American.

8 Cf. Benjamin Franklin's appreciation of the rattle-snake ([1775] 1987b: 746, 745) as an emblem of Americanness: "The Rattle-Snake is solitary, and associates with her kind only when it is necessary for ... preservation"; "the weapons with which nature has furnished her, she conceals in the roof of her mouth ... intimat[ing] that those things which are destructive to our enemies, may be to us not only harmless, but absolutely necessary to our existence". 
century perception of the U.S. national emblem: "[T] he American eagle, with outspread wings, ... has no great tenderness, even in her best of moods, and, sooner or later,- - oftener soon than late,- -is apt to fling off her nestlings with a scratch of her claw, a dab of her beak, or a rankling wound from her barbed arrows" (Hawthorne 1983a: 122-123). Bercovitch $(2002$ : 101, 121) has popularized a view regarding the insidious processes of quasi-official inculcation and manipulative acculturation, a literal double bind of the so-called self-validating American democracy: "It turns our world, imaginatively, into a system; it organizes our fantasies in ways that accommodate us to things as they are" "what begins as our independent, and often our oppositional perspective, leads us ... into the institutions of our colonizing culture". ${ }^{9}$ Unsurprisingly, flight from America proved quite early on to be a viable proposition: "Sometimes I've a mighty notion to just leave the country for good and all" (Twain [1885] 2001: 33). ${ }^{10}$ This urge is arguably most dramatically articulated in Edward Everett Hale's well-known tale "The man without a country": "D-n the United States! I wish I may never hear of the United States again!" (Hale 1863: 667), with the sentiment reverberating in Kurt Vonnegut's recent collection of more obviously politically motivated memoirs $A$ man without a country (2005).

When Horatio Greenough (1805-1852), the first U.S. professional sculptor, observed that Americans had no childhood, he meant that they had "no halffabulous, legendary wealth, no misty, cloud-enveloped background" (Bradshaw 1988: 12). Indeed, it is not difficult to note the absence of ethnic signifiers and of geographic exclusivity in the very name of the United States, to begin with. In a much larger sense, the original distinction, in fact the distinctive context of

$9 \quad$ In the essay "Myths of socialization and personality", Meyer (1986: 210) makes a similar point about American freedoms as a mirage, a kind of inverted totalitarianism, produced by concerted efforts of ideological systems: "[T]he American individual is free and empowered only within this confining scheme, and within it, freedom is compulsory". Cf. a more recent (radical) transcription of this appreciation: "In effect, the real horror lurks on the covert level, the former site of opposition, where things are worse than on the surface. Thus, the true extent of how deeply and comprehensively even an apparently adversarial literature is infected by the realities of America is finally revealed" (Fluck 2009: 14). For a broader perspective cf. Block (2002: 543): "The comforting view of 'conformism' as 'the nemesis of American individualism' becomes less convincing as the spectre of the organizationally shaped 'social self' ... is traced back to the Protestant saint situated within a morally directed and constraining community".

10 Tom Sawyer's bizarre idea at the end of Adventures of Huckleberry Finn to free Jim by having him dig a tunnel with a case-knife for thirty-seven years so that he could come out in China of all places, finds intertextually a more sombre if essentially metafictional counterpart in a contemporary novel in which the narrator contemplates liberating the besieged and distressed hero by letting him go out West to start a new life, only to propose eventually that it might not be the ultimate destination: "In my secret dreams, I like to think of Blue booking passage on some ship and sailing to China. Let it be China, then ... And from this moment on, we know nothing" (Auster 1990a: 232). 
the story of America, has been the scarcity of some of the most typical longterm formative circumstances of a people: such as common language, kinship, heredity, lore, deities, rites, rituals, pageantry or, last but by no means least, a standing army. De Tocqueville (1966: 731) would puzzle over this condition as an extraordinarily low-context cultural phenomenon: "[Can you] [p]icture ... a society without roots, memories, prejudices, routines, common ideas, or national character[?]". ${ }^{11}$ More specifically, and rather matter-of-factly, de Crevecoeur ([1782] 1981: 31) points out that the American lexicon is "but short in words of dignity and names of honor". In the quasi-formal "Information" addressed to those who might want to immigrate to America, Benjamin Franklin ([1784] 1987a: 976) advises that while ancestry may be of considerable value in Europe, it is a proposition (more properly: a commodity) that could not be brought to a worse market-place than that of the New World. The following view by the American social activist Dorothy Day from her autobiography The long loneliness (first published in 1952) happens to inform both much earlier and much later times: "We are afraid to be either proud of our ancestors or ashamed of them" (Day 1997: 16). It is revealing that Americans have never spoken of their country as fatherland or motherland, the nurturing appeal of the Statute of Liberty notwithstanding. With its "contempt for statutes and ceremonies, the / boundless impatience of restraint, / the loose drift of character" (Whitman [1855] 1982a: 332), the American nation has been identified in general figurative terms as "less of a vessel than a movement" (FitzGerald 1972: 7). Along this line of appreciation, America as a state looms in effect as "something comical in a sadly elephantine way" (Lundberg 1992: 14). The nearsacred founding text, the U.S. Constitution, has been called "all-sail-and-noanchor" - and as such "a weak symbol, lost in the mist that surrounds the American state" (Levin 1999: 18). Cultural anthropologists often argue that the United States is neither a viable body nor a viable population. It is a sentiment central to Archibald MacLeish's troubled poetic meditation "American letter" (1962: 73-74): "Neither a place it is nor a blood name. / ... neither a land nor a people. / ... It is strange to be born of no race and no people".

Having no obvious limits and no apparent oneness, the United States appears to fall outside the customary range and ken of Geistesgeschichte, Heimatkunst, Volkskunde and Volksseele. As Oliver Wendell Holmes would lament it in some absolute terms ([1860] 1872: 206): "There is no sufficient flavor of humanity in the soil out of which we grow". Rather wistfully, commenting on the native architectural landscape - "The American scene" - Henry James wrote: "[W]e

Typically invoked in this context are the comments of James Fennimore Cooper, Nathaniel Hawthorne and Henry James bemoaning the lack of adequate socio-cultural texture in America. 
have nothing to do with continuity, responsibility, transmission, and don't in the least care what becomes of us after we have served our present purpose" (James [1904-1905] 1993a: 361-362). Well before America got identified in the popular cultural parlance as a dis-united state of opportunistic amnesia where everything tends to get forgotten by the beginning of the new week, Transcendentalists would scoff at the sacredness of traditions and would specifically argue that no man was ever inspired through memory. As against the appreciation of European history anchored in time- and ruin-marked geography, the tale of America has been read not so much through celebrated events, places, localities, relics or shrines, as in the generic terms of the apparently effortless flux of time and the apparently natural expanse of space. Hawthorne's response ([1846] 1982a: 1129) to the site of the shot believed to have been heard around the world is in this regard symptomatic: "I have never found my imagination much excited by this, or any other scene of historic celebrity". Instead of seeking answers, solutions, and assurances in an identifiable circumscribed place, the apprehensive American protagonist is believed and supposed to fashion selfdefinition and forge one's own hierarchy of priorities and values against "nada on all sides" (Asselineau 1980: 10). ${ }^{12}$ This is how, as Thornton Wilder (1979: 12) phrases it, the American - thrown back upon oneself, disengaged effectively from time and place - seems to be permanently "at sea".

Halfway through the nineteenth century, The New Englander voiced a rather pathetic lament: "There is among us, what we do not know how otherwise to

12 Asselineau echoes here R. W. B. Lewis (1955: 86) for whom the very essence of American fiction is constituted by the question of what kind of "change" is possible for "the solitary figure surrounded by space". Warren (1984: 105) argues that it was James Fenimore Cooper who with The spy originated a tradition in the novel that has been recognized as peculiarly American: "[T]he principal setting was outside society, ... the principal character was a solitary male figure". Pearlman (1989a: 1) sums up many similar comments: "American literature, we are taught, is about space, open space, and the ways in which hearty or hesitant, defiant or defensive, American heroes experience both its potential and limitations". Jay (1997: 202) is not alone in openly denouncing this tradition: "As infamously immortalized in the criticism of D. H. Lawrence and Leslie Fiedler, 'classic' American literature has been seen as a field of boys' books, of tales out of school starring rebellious male adolescent loners whose every melancholy and lust deserves our most serious attention". A different response is offered by Macpherson (2000: 1) in her study of recent North American feminist fiction, namely, "to expand the canon of escape literature beyond the figure of the fleeing male" (to include, among others, such authors as Margaret Atwood, Joan Barfoot, Erica Jong, Anne Tyler). Macpherson points out that the most readily recognizable kind of escape in feminist fiction is the escape from the constraints of narrow gender roles, and identifies three main modalities of escape: "physical flight, excessive daydreaming, and emotional paralysis"; more generally, by becoming an escaper "the fictional female enters the space of the disappeared, a space which is easily transformed into the mythical or utopic" (Macpherson 2000: 3-7). Cf. Brown's appreciation (1990: 6) that feminist reinterpretations tend to project the (domestic) woman figure as "herself a runaway, a rebel". 
describe so well, a lack of the home feeling" ([Review] 1850: 432). There might show instead (in this case, rather tellingly, in The great American novel) a perverted interest in how it feels to make one's home "away from home instead of having it at home like everybody else" (Roth 1973: 137). Brown (1990: 5) argues that while individualism and domesticity both feature conspicuously as thematics of nineteenth-century American culture, they do so paradoxically - as "oppositional trajectories". ${ }^{13}$ Both more specifically and more broadly, de Tocqueville (1966: 560) observed that in America the family, if one were to contemplate the word in its classical meaning, simply "no longer exists". ${ }^{14}$ The elimination of any kind of overt interdependence between parents and children has become recognized as both an inevitable and a desirable arch goal in life. In the popular understanding, being grown up is tantamount to being able to displace oneself from one's origins and from the usual encrustations and encumbrances that might have defined one early on. "[O]nce created, weaned, and taught to read and write, the young American can easily shoulder his knapsack and choose his own way in the world ... [with] no roots to speak of in place, class, or religion" (Santayana 1937: 110).

Widmer (1965: 96; emphasis added) calls it a fillip that the following week the American protagonist may not only be far from where he right now happens to be, but also "far away from who he now is". In Hotel America, Lewis Lapham (1995: 140) argues that if America is about nothing else, it is about the invention of the self: "[W]e find ourselves set adrift at birth ... inheriting nothing except the obligation to construct a plausible self, ... a raft of identity". Emerson ([1844] 1983b: 492) appears to have been convinced that one can finally depend only on the validity of one's own agenda, in contradistinction and in fact as a reaction to how one may mundanely dress the garden, attend dinners, discuss the household, and all these things "make no impression, are [all] forgotten next week". Margaret Fuller (1869: 119) waxes even more radical: "If any individual live too much in relations ... [s/]he falls, after a while, into a distraction, or imbecility, from which

13 Dale Bailey in American nightmares (1999) discusses the haunted house formula in popular fiction as an enduring fixture in American culture; the author sees the haunted house from Edgar Allan Poe to Stephen King as a subversive symbol of the American Dream.

14 Coontz (1992: 16) argues that contrary to popular beliefs it was not industrialization that destroyed the traditional family: "Extended families have never been the norm in America; the biggest figure for extended-family households ever recorded in American history is 20 percent"; the critic emphasizes the point in her follow-up study The way we really are: "There never was a golden age of family life, a time when all families were capable of meeting the needs of their members and protecting them" (Coontz 1997: 2). 
[s/]he can only be cured by a time of isolation". This recognition strikes uncanny rapport with the admonition to defend oneself even against those who are nearest in friendship with us: "Stand off-keep away! Let there be an unfathomable gulf between us" (Burroughs 1882: 373). ${ }^{15}$ According to de Tocqueville (1966: 487), this is how ideas and understanding of one upon another are reduced "almost to nothing"; and they must be therefore "artificially created" ${ }^{16}$ Thoreau repeatedly argued that there is but little virtue in the action of masses of men, in unison with Emerson's: "[A]11 public ends look vague and quixotic beside private ones" "What I must do is all that concerns me" - "[Man] shall expect no cooperation" ([1844] 1983c: 567; [1841] 1983a: 263; [1860] 1983f: 1076). Even such keen observer of mores, manners, and morals as Henry James would in the prime of his life complain about the "horrible numerosity" of the public sphere: "I know too many people-I have gone in too much for society" (James 1955: 42). The nineteenth century, hailed by Emerson as the age of the first person singular, came to be associated with severance, dissociation and detachment: "The social sentiments are weak ... the natural affections feebler than they were" (Emerson 1965: 70). Charles Dickens's fictionalized account of the American social scene ([c. 1844] n.d.: 297) pictures it as overwhelmed by bullion: "Men were weighed by their dollars, measures gauged by their dollars; life was auctioneered, appraised, put up, and knocked down for its dollars". Toward the end of the century, the following became a well-recognized sentiment: "'Every man for himself, and the Devil take the hindmost.' It is upon this principle that we usually conduct business in this progressive and hurried age" (Parsons 1887: 168). ${ }^{17}$ When Frances Trollope ([1832] 1997: 93) notes that it is not in the temper of the American people either to give or to receive, she seems to be at one with de Tocqueville's recognition (1966: 478) that Americans defiantly "owe no man anything and hardly expect anything from anybody". According to Charles Dickens ([1842] 2000: 144): "One great blemish in the popular mind of America, and the prolific parent of an innumerable brood of evils, is Universal Distrust. Yet the American citizen plumes himself upon this spirit".

15 Charlie Chaplin was so struck by the lack of sociability in public spaces in America that he based his whole film saga on how the little man ventures out into the world and pathetically fails to find anybody to talk with: "Chaplin's films stress the failure of policemen to chat, and also of waiters and employers, and even of fellow workers" (McLuhan 1980: 147).

16 William Wordsworth is reputed to have concluded that America needed a civil war simply "to teach [the people there] the necessity of knitting the social ties stronger" (see Emerson [1856] 1983d: 775-776).

17 In "Worship" ([1860] 1983f: 1059), Emerson observes that especially in large cities "the population is godless, materialized,- no bond, no fellow-feeling ... These are not men, but hungers, thirsts, fevers, and appetites walking". In "Self-reliance" ([1841] 1983a: 262), Emerson castigates philanthropy and miscellaneous popular charities: "[D]o not tell me ... of my obligation to put all poor men in good situations. Are they my poor?". 
In 1890 Boston lawyers Samuel D. Warren and Louis D. Brandeis launched a well-received conceptualization of the notion of privacy simply as the right to be left alone, accepted soon as a classic transcription of negative liberty. Contemporary studies confirm that one of the biggest sources of unhappiness for Americans is the sense of being involuntarily involved in relationships. Cultural theorists seem to be in agreement about the absence of vital participatory needs, relevant shared convictions and complex collective meanings in the American sense of identity. As Pease (1987: 25) explains the American predicament: "[I]ndividuals who conceive of the life they can share together as a threat to their personal freedom cannot organize any vital community at all". Anecdotally, in "Considerations by the way", Emerson ([1860] 1983e: 1080) notes that when a person meets with an accident "the bystanders are animated with a faint hope that he will die". Steinbeck (2002: 332) is indeed convinced that Americans are prone to form "a wide circle around a dying man on the pavement" and "a girl screaming for help in the streets draws only slammed doors, closed windows, and silence". Emblematic of the fortunes of utopian experiments in collectivism in real life (such as Icarians, Harmonists, Perfectionists, Owenites, Ruskinites), the country's most famous single literary attempt half-way through the nineteenth century to create an ideal community, to embrace blithesome co-existence, proved to be a pathetic failure: "I am weary of this place, and sick to death of playing at philanthropy and progress" - "Paradise, indeed! ... Nor, with such materials as were at hand, could the most skilful architect have constructed any better" (Hawthorne [1852] 1983b: 830, 639).

Notions such as self-culture and self-made man, promoted originally as catchwords of the ideology of conscious construction and cultivation of character, instead of effecting nobles oblige have been transcribed simply into feeling good about oneself. This recognition appears especially poignant against the backdrop of what de Crevecoeur (1981: 182) perceived as the "charm" of native American (Indian) life: "[T]here must be in their social bond something singularly captivating and far superior to anything to be boasted of among us". Instead, there had been detected early on an oxymoronic sense of "scattered congregation", purposely "insular and incommunicable" (Melville [1851] 1983a: 830). Mrs. Burton Harrison's nineteenth-century essay "Good Americans" (1898: 334) features a blunt confession: "We are too busy, too selfish, too bent on our [own] devices". The protagonist of a contemporary novel by the title Americana - young, good-looking and successful, too - comes up with a striking admission: "[The] most important thing to find out was the degree of hostility ... All you had to do was to look at the people who were looking at you ... three out of four were hostile" (DeLillo [1971] 1989: 4). ${ }^{18}$

18 In practical terms of legal culture, itself indicative of the absence of self-apparent ethical and moral communal values, the propensity to sue is recognized as a routine part of every- 
In deep-down essence as well as in everyday spirit, all American ideologies are believed to be rooted in the discourse of space. Charles Olson (1968: 15) observes: "An American / is a complex of occasions, / themselves a geometry / of spatial nature". An essential aspect of Americanism is believed to be the particular stance one actually assumes in space. Philosophically and poetically, Thoreau advocates lying on one's back with nothing between the eyes and the stars - "nothing but space" ([1851] 1949/II: 381). Whitman exultantly inhales "great draughts of space" and celebrates the "centripetal isolation of a human being" ([1855] 1982b: 300; [1871] 1982c: 958). It seems to be a persistent New World belief that true individualism and freedom are possible only in the abandon of open space. After the confrontation with the continental boundlessness, the emergence of the anonymity of the urban environment in the nineteenth century would eventually extend the street as the substitute or alternative to the pathways of forests and streams, with the metropolitan pedestrian instinctively subscribing to its lore (Patten 1909: 58).

Gertrude Stein ([1936] 1973: 53) posits that the single most important factor shaping America is there being "more space where nobody is than where anybody is". Wallace Stevens, who would define the world as a collection of objects and behaviours in space, concedes nonetheless that the American Sublime, entertained as a private vista of open air magnified into a protracted vision, can easily collapse into a non-negotiable "[E]mpty spirit / In vacant space" (Stevens 1977a: 131). Equally, this sensation can be visited upon a local ranch hand - "It's all a bunch of nothing ... so much of it you can't tell where you're going or where you've been" (Ehrlich 1985: 2) - and on an enthusiastic visitant from far afield: "Here you are ... [with all this] space and the most overpowering sky in the world, and there's nothing to say" (Perkins 1994: 85). Nigro (1984: 87) sees it as one of the most poignant ironies "in a land and literature renowned for its sense of place and the salutary effect of place on a person, the American hero should so often be depicted as a displaced person". It turns out that the alluring American thereness is likely not fixed but sliding, effecting ambiguous surfaces of no-man's land. In this kind of milieu that apparently begins and leads everywhere, the feeling of being alone in space translates itself ultimately not only as the trepidation of being left alone with America, but more dauntingly as being left alone with one's own self. "[T]o lose a sense of where you are implies the danger of losing a sense of who you are" (Ellison [1952] 1972: 564). ${ }^{19}$

day reality in the United States, a prominent and celebrated element of the country's broader adversarial and litigious context.

19 The American space can induce an oppressive, possibly agrophobic denudation of one's actual size. "[W]e are sick with space. / Its contemplation makes us out as small / As a brief 
Cahir (1999: xiii) argues that it is inherent to the American experience to accept solitude and loneliness - "even to welcome them". However, while Americans tend to move with a sense of abandon, the abandoning leaves its mark. "[W]e Americans, we ride wide and handsome, that's what we Americans are ... but it's riding all alone ... and if you get kind of lonesome you get to be no good" (Stein 1998: 769-770). As Flannery O'Connor ([1952] 1988a: 93) identifies the conundrum: "Where you come from is gone, where you thought you were going to never was there, and where you are is no good unless you can get away from it. Where is there a place for you to be? No place". A cultural critic talks more broadly of the American syndrome of nowhereness: "In every corner of the nation we have built places unworthy of love and move on from them without regret. But move on to what? Where is the ultimate destination when every place is Noplace?" (Kunstler 1993: 173). Schweitzer (2006: 6) argues that from the very beginning the configuration of the American 'imperial self' was implanted with the seeds of its own subversion. In a more general than just spatial sense, loneliness is the price to be paid for the effusion of egotism, a circumstance of unfettered, self-contained individualism and radical autonomy. Flight from the socially prescribed modes of existence does not of itself insure a happy asylum. To Howe (1986: 4; emphasis added), "[t]he burden of isolation is of course a central theme in American literature"; and Petesch (1989: 27) claims that one cannot but be struck by a "pattern" of aloneness in classic American fiction. ${ }^{20}$ In the essay "Look homeward, Americans", Carson McCullers (1975: 217) argues that while essentially all men are lonely, Americans are the loneliest of all; their quality of longing having turned the feeling into some-

epidemic of microbes" (Frost 1967a: 473). Paul Auster's eerie modern urban odysseys are ultimately also about how aloneness in space envelops people and shuts them in - and with it comes "a terror worse than anything [one] has ever known" (Auster 1990a: 186).

20 Not surprisingly, to many commentators there emerges something like a pattern of aloneness among nineteenth-century American literati themselves. Emily Dickinson's programmatic seclusion, Thoreau's pursuit of solitude, or Hawthorne's and Melville's spells of social estrangement have become legendary. Arvin (1962: 546) places also Henry James in this category: "Hawthorne's theme of estrangement, the Ishmaelite theme that obsessed Melville, were driven by Henry James to a formulation still more extreme; and expatriation, the frankest form of desertion, became both his literary munition and his personal fate". Bell (1980: 32) extends the field by pointing out that Charles Brockden Brown and Washington Irving, even though they did not hold consistently to the antisocial implications of their first critical decisions, turned to writing as "an escape from, even a defiance of, the 'real' legal business for which they were being trained". Bewley (1963:15) asserts that there was really "one subject available to the nineteenth-century American novelist - his own unhappy plight. And the essence of that plight was his isolation". According to Lentricchia (1991a: 5-6): "The American literary way has from the start been fiercely antinomian, suspicious, even 'paranoid' ... [It] characterizes the main take on our culture from Anne Hutchinson and Emerson to Pynchon and DeLillo". 
thing like "a national disease". It emerges that the stance of renunciation does not only undermine the impersonal regime of social decorum but finally threatens personal integrity as well. Emily Dickinson (1960: 365-366) would realize that renunciation may prove to be a costly virtue, the putting out of eye (I) "the Choosing / Against itself". What is thought of as the ultimate reality, the self, may become the ultimate un-reality, with excessive individualism leading to obsessive and untoward states. "[A]t first [it] only dams the spring of public virtues, but in the long run it attacks and destroys all the others too" (de Tocquevillle 1966: 477). Americans have been actually repeatedly advised about the perilous dynamic of their lives. De Tocqueville (1966: 478) warns that man given to radical self-determination risks being "thrown on himself alone and there is danger that he may be shut up in the solitude of his own heart". In the twentieth century, Hunter S. Thompson (1979: 98) would poignantly identify the malady of infinite aspiration and instant gratification, the pandemic of rampant, vainglorious self-fulfillment as "the dead end loneliness of a man who makes his own rules". It is a condition reducible finally to that of "a little boy left alone in a big house, who knew that now he could do anything he wanted to, but found that there was nothing he wanted to do--" (Fitzgerald [1945] 1965: 79). Self-legislation, atomistic self-actualization and pursuit of some ultimate freedom can become a lugubrious or outright self-consuming wild-goose chase: "They see it close enough to know its charms, but they do not get near enough to enjoy it, [which] is the reason for the strange melancholy ... and of that disgust with life sometimes gripping [Americans]" (de Tocqueville 1966: 510). Marx (1967: 364) strikes in this context a near-apocalyptic tone: "[I]n the end the American hero is either dead or totally alienated from society, alone and powerless, like the evicted shepherd of Virgil's eclogue". ${ }^{21}$

This is where American literature appears to add to a larger ongoing debate over the country's ruptured socio-cultural and existential condition. "From big city to the remotest rural trailer court, our civic life is tattered and frayed" (Kunstler 1998: 22). The nineteenth-century misgivings - "[A]re we the noncrystalizing people, the people for ever set apart[?]" (Swisshelm 1876: 618) seem to be even more vocal today. At times, it may appear that members of any one American community do not live in the same country. "[Do] Americans reveal a flaw in their character: the inability to build a viable community? ... Americans are enormously energetic and enterprising people. But can they also live together?" (Rockland 1990: 61). According to philosopher and political activist Jerome M. Segal (2003: 3), the ambivalence that many Americans feel

This seems to be echoing R. W. B. Lewis's dramatization (1955: 128) of the trials of the American hero, "defeated, perhaps even destroyed - in various versions of the recurring anecdote hanged, beaten, shot, betrayed, abandoned". 
toward their own lives is part and parcel of the American negative legacy: "There is always that nagging question, 'Is this really the way to live?". Behind America's manifest grandiosity there has always lurked a deep anxiety that the country may have been sending false signals all along. In Love in the ruins, Walker Percy $(1971: 3,56)$ pushes skepticism so far as to venture that not only may God have removed his blessing from the United States, but that it is possible that from the very beginning America "never did work", that there has always been some larger "flaw" in its design. Doubts and questions of this nature inform an ever-growing array of popular studies of various ideological, cultural, and methodological persuasions. Taken at face value, indicative of both selfmockery and self-doubt, these studies lend support to the provocative thesis that all the tensions of the world may have been, as it were, "imported" by the United States (Rorty 1999: 4; Ledeen 2000: 27). Even if this is projecting a rather familiar litany of reservations and recriminations, the contemporary American jeremiad makes for a disconcerting reading. This recognition is richly illustrated by such haunting titles - and it seems that everybody could easily extend their own list - as The culture of narcissism, Escape from freedom, The lonely crowd, The uncommitted, A nation of strangers, The broken hearth, The pursuit of loneliness, The connection gap, The segmented society, Culture of complaint, Party of one, The cynical society, A culture of conspiracy, America's crisis of values, The unheavenly city, Pathology in American culture, The de-valuing of America, Empire of illusion, My American unhappiness, Death of a nation, The lost continent, or Quitting America.

In the context, to invoke Moby-Dick's larger vision, America's trajectory its ultimate destination perpetually in dispute and potentially always under suspicion to begin with - seems to resemble the loomings of Melville's desultory Rachel in search for her missing children. A sharp contrast to the agenda brought by the early-seventeenth-century cross-Atlantic cruisers, these considerations and concerns appear especially pertinent at the time of the apparent crisis of the very notion of Americanness. ${ }^{22}$ It is indeed possible to argue that

22 To its acolytes, pundits and proponents the prevailing tenor of U.S. culture has been of course fundamentally sanguine. Throughout much of American history, voices of doubt have been powerfully rivalled especially by faith in the rewards of material progress. However, historian Henry F. May (1983: 54) actually identifies formally "the other American tradition" - the tradition of "alienation and self-doubt". By way of example, May points out that the favourite popular hero of U.S. history is not the progressive and optimistic Thomas Jefferson, but the brooding, melancholy and troubled Abraham Lincoln. A very similar general appreciation to May's may be found earlier with Henry Adams (1918: 297), according to whom "There [in Washington as against New York or Chicago] the American showed himself, four times in five, as a quiet, peaceful, shy figure, rather in the mould of Abraham Lincoln, somewhat sad, sometimes pathetic, once tragic; or like Grant, inarticulate, uncertain, distrustful of himself, still more distrustful of others; and awed by money". 
"the concept known as America has played itself out", that in some overall sense it is no longer a workable proposition (Auster 2010: 72). At a certain point, however, a cautionary question needs to be asked. To what extent can the above anecdotal observations and random citations reflect the genuine circumstance of the so-called habits (habitus or hexis) of the heart - a legitimate part of the ongoing discourse of dominant, residual and emergent cultural commons, part of the collective efforts through which a particular people strives to understand itself - and when are they in danger of uncontrollably lapsing into a mechanical copulation of banalities, slogans, stereotypes and clichés. As O'Connor (2007a: 1) points out, the appreciation of the "ordinariness" of much of American life tends to get lost as the image of the country is being not only constantly valorized, ideologized and politicized but fantasized and sensationalized, and thus regrettably caricatured and fetishized.

\section{REFERENCES}

Adams, Henry

1918 The education of Henry Adams: An autobiography. Boston: Houghton Mifflin. Anderson, Quentin

1972 The imperial self: An essay in American literary and cultural history. New York: Vintage.

Arvin, Newton

1962 "Individualism and the American writer", in: Morton Dauwen Zabel (ed.), 544-549. Asselineau, Roger

1980 The transcendentalist constant in American literature. New York: New York University Press.

Auster, Paul.

1990 The New York trilogy. Harmondsworth: Penguin Books.

1990a Ghosts, in: Paul Auster 1990, 159-232.

2010 Sunset Park. New York: Henry Holt.

Bell, Michael Davitt

1980 The development of American romance. Chicago: The University of Chicago Press.

Bercovitch, Sacvan

2002 "Deadpan Huck, or, what's funny about interpretation", The Kenyon Review 24/3-4: 90-134.

Bewley, Marius

1963 The eccentric design: Form in the classic American novel. New York: Columbia University Press.

Block, James E.

2002 A nation of agents: The American path to a modern self and society. Cambridge, MA: The Balknap Press of Harvard University Press. 
Boorstin, Daniel J.

1965 The Americans: The national experience. New York: Vintage.

Bourne, Randolph Silliman

1992 The radical will: Selected writings, 1911-1918. (Edited by Olaf Hansen.) Berkeley, CA: University of California Press.

Bradford, William

1991 Of Plymouth Plantation, in: James E. Miller, Jr. (ed.), 50-83.

Bradshaw, Michael John

1988 Regions and regionalism in the United States. Jackson, MS: University Press of Mississippi.

Brown, Gillian

1990 Domestic individualism. Berkeley, CA: University of California Press.

Browne, Ray B. - Marshall W. Fishwick - Kevin O. Browne (eds.)

1990 Dominant symbols in popular culture. Bowling Green, OH: Bowling Green State University Popular Press.

Burroughs, John

1882 "Henry D. Thoreau", The Century Magazine XXIV/3: 368-379.

Cahir, Linda Costanzo

1999 Society and solitude in the works of Herman Melville and Edith Wharton. Westport, CT: Greenwood Press

Coontz, Stephanie

1992 The way we never were. New York: Basic Books.

1997 The way we really are. New York: Basic Books.

Cooper, James Fenimore

1964 The pioneers. New York: The New American Library.

1984 The prairie. Laurel, NY: Lightyear Press.

2001 Notions of the Americans. (Edited by Bradley J. Birzer and John Willson.) Washington, D.C.: Regnery Publishing.

Day, Dorothy

1997 The long loneliness. New York: HarperSanFrancisco.

de Creveceour, St. John, J. Hector

1981 Letters from an American farmer; Sketches of eighteenth-century America. (Edited by Albert E. Stone.) New York: Penguin Books.

de Tocqueville, Alexis

1966 Democracy in America. (Edited by J. P. Mayer and Max Lerner, translated by George Lawrence.) New York: Harper \& Row.

DeLillo, Don

1989 Americana. Harmondsworth: Penguin Books.

Dickens, Charles

[n.d.] The life and adventures of Martin Chuzzlewit. London: Thomas Nelson \& Sons.

2000 American notes for general circulation. (Edited by Patricia Ingham.) New York: Penguin Books.

Dickinson, Emily

1960 The complete poems of Emily Dickinson. (Edited by Thomas H. Johnson.) Boston: Little, Brown.

Ehrlich, Gretel

1985 The solace of open spaces. New York: Viking Press. 


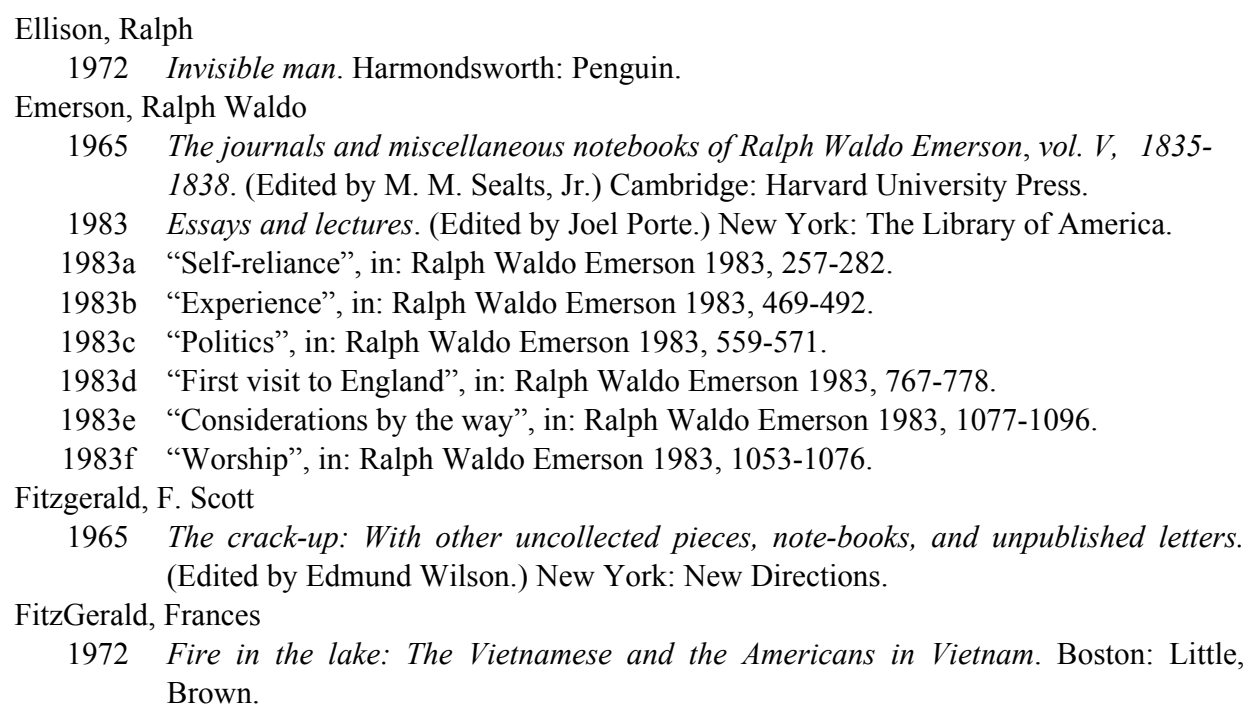

Fluck, Winfried

2009 "American literary history and the romance with America", American Literary History 21/1: 1-18.

Franklin, Benjamin

1987 Writings. (Edited by J. A. Leo Lemay.) New York: The Library of America.

1987a "Information to those who would remove to America", in: Benjamin Franklin 1987, 975- 983.

1987 b "The rattle-snake as a symbol of America", in: Benjamin Franklin 1987, 744-746.

Franzen, Jonathan

2003 How to be alone: Essays. New York: Picador.

Frost, Robert

1967 Complete poems of Robert Frost. New York: Holt, Rinehart and Winston.

1967a "The lesson for today", in: Robert Frost 1967, 471-476.

Fuller Ossoli, Margaret

1869 Woman in the nineteenth century, and kindred papers. (Edited by Arthur B. Fuller.) New York: The Tribune Association.

Gass, William H.

1968 In the heart of the heart of the country. New York: Harper \& Row.

Hale, Edward Everett

1863 "The man without a country", The Atlantic Monthly XII/74: 665-680.

Harrison, Burton

1898 "Good Americans", The Century LV/3: 330-339.

Hawthorne, Julian

1884 Nathaniel Hawthorne and his wife. Boston: James R. Osgood.

Hawthorne, Nathaniel

1982 Tales and sketches. (Edited by Harvey Pearce.) New York: The Library of America.

1982a "Preface to Mosses from an old Manse", in: Nathaniel Hawthorne 1982, 1123-1149.

1983 Novels. (Edited by Millicent Bell.) New York: The Library of America.

1983a The scarlet letter, in: Nathaniel Hawthorne 1983, 115-345. 
1983b The Blithedale romance, in: Nathaniel Hawthorne 1983, 629-848.

Hemingway, Ernest

1993 The first forty-nine stories. London: Arrow Books.

1993a "The battler", in: Hemingway 1993, 123-132.

Holmes, Oliver Wendell

1872 The professor at the breakfast-table. Boston: James R. Osgood.

Howe, Irving

1986 The American newness: Culture and politics in the age of Emerson. Cambridge, MA: Harvard University Press.

James, Henry

1955 The notebooks of Henry James. (Edited by F. O. Matthiessen and Kenneth B. Murdock.) New York: George Braziller.

1993 Collected travel writings: Great Britain and America. (Edited by Richard Howard.) New York: The Library of America.

1993a "The American scene", in: Henry James 1993, 351-757.

Jay, Gregory S.

1997 American literature and the culture wars. Ithaca, NJ: Cornell University Press.

Kunstler, James Howard

1993 The geography of nowhere. New York: Simon \& Schuster.

1998 Home from nowhere. New York: Touchstone.

Lapham, Lewis

1995 Hotel America. New York: Verso.

Ledeen, Michael A.

2000 Tocqueville on American character. New York: St. Martin's Press.

Lentricchia, Frank (ed.)

1991 Introducing Don DeLillo. Durham, NC: Duke University Press.

1991a "The American writer as bad citizen", in: Frank Lentricchia (ed.), 1-6.

Levin, Daniel Lessard

1999 Representing popular sovereignty: The constitution in American political culture. Albany, NY: State University of New York Press.

Lewis, R. W. B.

1955 The American Adam: Innocence, tragedy, and tradition in the nineteenth century. Chicago: The University of Chicago Press.

Lundberg, Ferdinand

1992 Politicians and other scoundrels. Fort Lee, NJ: Barricade Books.

MacLeish, Archibald

1962 The collected poems of Archibald MacLeish. Boston: Houghton Mifflin.

Macpherson, Heidi Slettedahl

2000 Women's movement: Escape as transgression in North American feminist fiction. Amsterdam - Atlanta, GA: Rodopi.

Marx, Leo

1967 The machine in the garden: Technology and the pastoral ideal in America. New York: Oxford University Press.

May, Henry F.

1983 Ideas, faiths, and feelings: Essays on American intellectual and religious history 1952-1982. New York: Oxford University Press. 
McCullers, Carson.

1975 The mortgaged heart. (Edited by Margarita G. Smith.) Harmondsworth: Penguin.

McLuhan, Marshall

1980 "Inside on the outside, or the spaced-out American", The Antigonish Review 76-75: $144-152$.

Melville, Herman

1983 Redburn; White-Jacket; Moby-Dick. (Edited by G. Thomas Tanselle.) New York: The Library of America.

1983a Moby-Dick, in: Herman Melville 1983, 771-1408.

Meyer, John M.

1986 "Myths of socialization and personality", in: Thomas C. Heller et al. (eds.), 208- 210.

Miller, Douglas T.

1970 The birth of modern America 1820-1850. Indianapolis: Bobbs-Merrill.

Miller, James E., Jr. (ed.)

1991 Heritage of American literature. Vol. I. San Diego: Harcourt Brace Jovanovich.

Nabokov, Vladimir

1997 Lolita. New York: Vintage International.

Newfield, Christopher

1996 The Emerson effect: Individualism and submission in America. Chicago: The University of Chicago Press.

Nigro, August J.

1984 The diagonal line: Separation and reparation in American literature. Cranbury, NJ: Associated University Presses.

O'Connor, Brendon

2007a “What is anti-Americanism?”, in: Brendon O'Connor (ed.), 1-22.

O’Connor, Brendon (ed.)

2007 Anti-Americanism. Oxford: Greenwood World Publishing.

O'Connor, Flannery

1988 Collected works. (Edited by Sally Fitzgerald.) New York: The Library of America.

1988a Wise blood, in: Flannery O'Connor 1988, 1-131.

Oliver, Robert T.

1965 History of public speaking in America. Boston: Allyn and Bacon.

Olson, Charles

1968 Maximus IV, V, VI. London: Charles Goliard.

Parsons, George Fredric

1887 "The growth of materialism", The Atlantic Monthly LX/358: 157-172.

Patten, Simon Nelson

1909 Product and climax. New York: B.W. Huebsch.

Pearlman, Mickey (ed.)

1989 American women writing fiction. Lexington, KY: University Press of Kentucky.

1989a "Introduction", in: Mickey Pearlman 1989, 1-8.

Pease, Donald E.

1987 Visionary compacts: American Renaissance writings in cultural context. Madison, WI: The University of Wisconsin Press.

Percy, Walker

1971 Love in the ruins. New York: Farrar, Straus \& Giroux. 
Perkins, Emily

1994 “Can't beat it", Sport (New Zealand) 12: 79-89.

Petesch, Donald A.

1989 A spy in the enemy's country: The emergence of modern black literature. Iowa City: University of Iowa Press.

Poirier, Richard

1966 A world elsewhere. London: Oxford University Press.

[Review]

1850 John Ruskin, The seven lamps of architecture, The New Englander VIII: 418-434.

Rockland, Michael Aaron

1990 “American mobility”, in: Ray B. Browne et al. (eds.), 59-74.

Rorty, Richard

1999 Achieving our country: Leftist thought in twentieth-century America. Cambridge, MA: Harvard University Press.

Roth, Philip

1973 The great American novel. New York: Holt, Rinehart and Winston.

Rowe, Joyce A.

1988 Equivocal endings in classic American novels. Cambridge: Cambridge University Press.

Santayana, George

1937 Character and opinion in the United States. New York: Charles Scribner's Sons.

Sardar, Ziauddin - Merryl Wyn Davies

2004 American terminator. New York: The Disinformation Company.

Schweitzer, Ivy

2006 Perfecting friendship: Politics and affiliation in early American literature. Chapel Hill, NC: The University of North Carolina Press.

Segal, Jerome M.

2003 Graceful simplicity: The philosophy and politics of the alternative American Dream. Berkeley, CA: University of California Press.

Semrau, Janusz

2011 "Dubious American license: The first in flight", Studia Anglica Posnaniensia 46/4: 97105.

2012a Transcribing the territory; or, rethinking resistance. A study in classic American fiction. $\left(2^{\text {nd }}\right.$ ed.) Frankfurt am Main: Peter Lang.

2012 b "Vertiginous pull of negative rhetoric: The American 'NO! in thunder", Studia Anglica Posnaniensia 47/1: 61-71.

Stein, Gertrude

1973 The geographical history of America, or the relation of human nature to the human mind. New York: Vintage.

1998 Writings 1932-1946. (Edited by Catherine R. Stimpson and Harriet Chessman.) New York: The Library of America.

Steinbeck, John

2002 America and Americans, and selected nonfiction. (Edited by Susan Shillinglaw and Jackson J. Benson.) New York: Viking Penguin.

Stevens, Wallace

1977 The collected poems of Wallace Stevens. New York: Alfred A. Knopf.

1977a "The American sublime", in: Wallace Stevens 1977, 130-131. 
Swisshelm, Jane Grey

1876 "The American character", The Galaxy XXII: 618-623.

Tanner, Tony

1971 City of words: American fiction 1950-1970. New York: Harper \& Row.

Thomson, Hunter S.

1979 The great shark hunt. New York: Summit Book.

Thoreau, Henry David

1949 The Journal of Henry D. Thoreau. 14 vols. (Edited by Bradford Torrey and Francis H. Allen.) Boston: Houghton Mifflin.

1975 The selected works of Thoreau. (Edited by Henry Seidel Canaby, revised by Walter Harding.) Boston: Houghton Mifflin.

1975a Walden, in: Henry David Thoreau 1975, 245-465.

Trollope, Frances

1997 Domestic manners of the Americans. (Edited by Pamela Neville-Sington.) HarTwain, Mark mondsworth: Penguin Books.

2001 Adventures of Huckleberry Finn. (Edited by Victor Fisher and Lin Salamo.) Berkeley, CA: University of California Press.

Viereck, Peter

1956 The unadjusted man: A new hero for Americans. Boston, MA: The Beacon Press.

Warren, Joyce W.

1984 The American Narcissus. New Brunswick, NJ: Rutgers University Press.

Whitman, Walt

1982 Complete poetry and collected prose. (Edited by Justin Kaplan.) New York: The Library of America.

1982a "Song of the broad-axe", in: Walt Whitman 1982, 330-341.

1982 b "Song of the open road", in: Walt Whitman 1982, 297-307.

1982c "Democratic vistas", in: Walt Whitman 1982, 929-994.

Widmer, Kingsley

1965 The literary rebel. Carbondale - Edwardsville: Southern Illinois University Press.

Wilder, Thornton

1979 American characteristics and other essays. (Edited by Donald Gallup.) New York: Harper \& Row.

Wister, Owen

1920 A straight deal; or, the ancient grudge. New York: Macmillan.

Wolfe, Tom

1968 The electric kool-aid acid test. New York: Bantam.

Zabel, Morton Dauwen (ed.)

1962 Literary opinion in America. (3rd ed.) New York: Harper \& Row. 